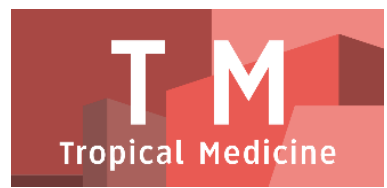

PAPER - OPEN ACCESS

Hubungan Perilaku Perawatan Kaki dengan Terjadinya Komplikasi Luka Kaki Diabetes pada Pasien Diabetes Melitus Tipe 2 di Puskesmas Tuntungan Kota Medan

\author{
Author : Rina Amelia \\ DOI $\quad: 10.32734 /$ tm.v1i1.56 \\ Paper Page : $124-131$
}

Volume 1 Issue 1 - 2018 TALENTA Conference Series: Tropical Medicine (TM)

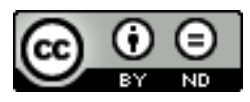

This work is licensed under a Creative Commons Attribution-NoDerivatives 4.0 International License.

Published under licence by TALENTA Publisher, Universitas Sumatera Utara
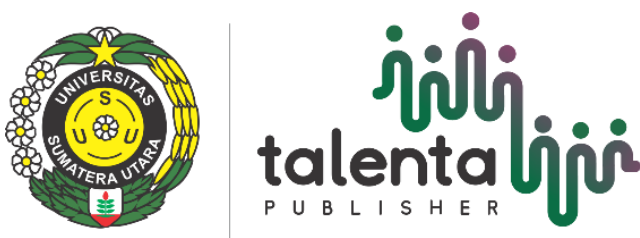


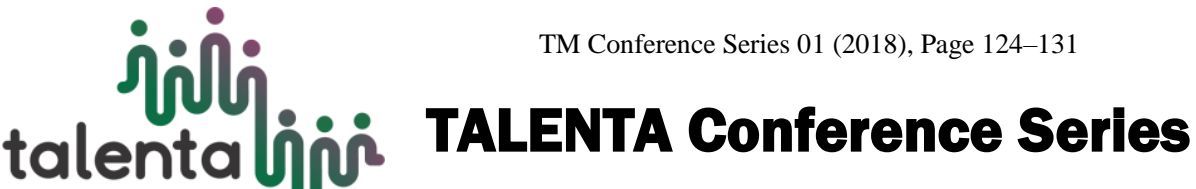

Available online at https://talentaconfseries.usu.ac.id

\section{Hubungan Perilaku Perawatan Kaki dengan Terjadinya Komplikasi Luka Kaki Diabetes pada Pasien Diabetes Melitus Tipe 2 di Puskesmas Tuntungan Kota Medan}

\author{
Rina Amelia \\ Depatemen Kedokteran Komunitas, Fakultas Kedokteran USU \\ drrinaamelia@gmail.com
}

\begin{abstract}
Abstrak
Diabetes merupakan peyakit kronis yang disebabkan karena kekurangan atau tidak efektifnya insulin yang dihasilkan. WHO memperkirakan jumlah penduduk dunia yang menderita diabetes pada tahun 2030 akan meningkat paling sedikit menjadi 366 juta. Indonesia menempati urutan keempat terbanyak dengan prevalensi 8,6\% dari seluruh penduduk. Diabetes akan menjadi masalah yang serius apabila telah terjadi komplikasi, salah satu komplikasi adalah luka kaki diabetes (diabetic foot). Komplikasi luka kaki diabetes menjadi penyebab lamanya hospitalisasi dan amputasi lebih dari $90 \%$ ekstremitas bawah pada penderita diabetes. Tujuan penelitian adalah untuk menganalisis hubungan perilakuperawatan kaki dengan terjadinya komplikasi luka kaki diabetes pada pasienDM tipe 2di Puskesmas Tuntungan Medan. Disain penelitian adalah analitik dengan pendekatan cross sectional. Populasi penelitian adalah seluruh penderita DM tipe 2 yang datang ke Puskesmas Tuntungan Medan dengan sampel sebanyak 83 orang (consecutive sampling). Instrumen penilaian perilaku perawatan kaki yang digunakan adalah Questions determining the knowledge and practice about foot careyang terdiri dari 15 item pertanyaan. Analisis data menggunakan uji statistik chi square. Hasil penelitian menunjukkansebanyak 48 orang pasien diabetes $(57,8 \%)$ memiliki perilaku yang buruk terhadap perawatan kaki, sebanyak 29 orang (349\%) mempunyai riwayat komplikasi luka kaki dibetes (ulkus). Hasil analisis chi square menunjukkan terdapat hubungan antara perilaku perawatan kaki diabetes dengan kejadian komplikasi luka kaki diabetes pada pasien DM tipe 2 di Puskesmas Tuntungan Medan $(p<0.05)$. Perilaku perawatan kaki sangat berperan terhadap terjadinya luka kaki diabetes. Untuk membentuk perilaku yang baik dibutuhkan edukasi oleh dokter maupun oleh petugas kesehatan kepada pasien diabetes.
\end{abstract}

Kata Kunci: Diabetes Melitus Tipe 2; Perilaku Perawatan Kaki; Luka Kaki Diabetes

\section{Pendahuluan}

Diabetes melitus (DM) merupakan penyakit kronis yang disebabkan karena kekurangan produksi insulin atau oleh tidak efektifnya insulin yang dihasilkan. Hal ini menyebabkan peningkatan konsentrasi glukosa dalam darah (hiperglikemia), kondisi yang akan merusak banyak sistem tubuh, khususnya pembuluh darah dan saraf [45]. Diabetes secara awam juga dikenal sebagai penyakit kencing manis atau penyakit gula, merupakan penyakit kronis yang bersifat progresif yang diakibatkan oleh perilaku tidak sehat, kurang aktifitas fisik, dan stres sehingga dapat menimbulkan berbagai komplikasi kronis pada berbagai organ vital [21]. 
World Health Organization (WHO) memperkirakan jumlah penduduk dunia yang menderita diabetes pada tahun 2030 akan meningkat paling sedikit menjadi 366 juta. Indonesia menempati urutan ke- 4 terbesar dalam jumlah penderita diabetes dengan prevalensi $8,6 \%$ dari total penduduk. Hal ini menunjukkan bahwa penyakit diabetes merupakan masalah kesehatan masyarakat yang sangat serius di Indonesia. Namun, perhatian terhadap penanganan diabetes melitus di negara berkembang masih kurang, terutama tentang komplikasi yang ditimbulkan akibat diabetes [43].

Peningkatan kadar gula darah yang tidak terkontrol dalam jangka waktu yang lama dapat menimbulkan berbagai macam komplikasi antara lain penyakit jantung dan pembuluh darah yang akan menyebabkan serangan jantung, stroke, gagal jantung, peripheral artery disease (insufisiensi aliran darah arteri), kerusakan saraf mata (retinopati), penyakit ginjal (nefropati), dan kerusakan saraf (neuropathy) yang akan mengakibatkan infeksi dan luka kaki diabetes, ganggguan kaki diabetes, hingga amputasi mayor [21].

Luka kaki diabetes merupakan komplikasi kronik diabetes berupa luka terbuka pada permukaan kulit yang dapat disertai adanya kematian jaringan setempat [31]. Prevalensi penderita luka kaki diabetes kurang lebih $12-15 \%$ dari seluruh penderita diabetes dan biasanya terletak pada ekstremitas bawah. Luka kaki diabetes menjadi penyebab lama waktu hospitalisasi dari pada komplikasi diabetes lainnya. Luka kaki diabetes dapat berpotensi terjadinya komplikasi dan menyebabkan lebih dari $90 \%$ amputasi ekstremitas bawah pada penderita diabetes (American Diabetes Association). Tingkat kematian karena amputasi kaki diabetes sebanyak $11-41 \%$ setelah setahun amputasi, 20 - 50\% setelah 3 tahun pasca amputasi dan 39- 80\% setelah 5 tahun pasca amputasi, di mana angka kematian ini diperburuk oleh penyakit yang berbahaya lainnya [30]. Prevalensi terjadinya luka kaki diabetes di Indonesia sekitar $13 \%$ penderita di rawat di rumah sakit dan $26 \%$ penderita rawat jalan [31]. Perawatan kaki yang baik akan mencegah terjadinya luka kaki diabetes. Perilaku perawatan yang baik sangat dipengaruhi tingkat pengetahuan pasien diabetes. Semakin bagus pengetahuannya tentu akan semakin bagus perilaku perawatannya.

\section{Metode}

Penelitian ini merupakan penelitian analitik dengan pendekatan cross sectional yang bertujuan untuk menganalisis hubungan perilakuperawatan kaki dengan kejadian komplikasi luka kaki diabetes pada pasien Diabetes melitus tipe 2 di Puskesmas Tuntungan Kota Medan. Populasi penelitian adalah seluruh penderita Diabetes melitus tipe 2 yang datang berobat jalan ke Puskesmas Tuntungan Medan. Sampel penelitian sebanyak 83 orang ditentukan dengan teknik consecutive sampling.

\section{Instrumen Penelitian}

Untuk menilai perilaku perawatan kaki pada pasien diabetes digunakan kuesioner Thequestions determining the knowledge and practice about foot care yang dikembangkan oleh Hasnanin dan Sheikh (2009) dan telah dimodifikasi oleh Diani (2013). Kuesioner ini diterjemahkan melalui cara Back Translation.Kuesioner ini terdiri dari 15 item pertanyaan dengan skor untuk setiap pertanyaan.Untuk menilai terjadinya komplikasi luka kaki diabetes dilakukan secara wawancara observasi langsung kepada penderita diabetes.

\section{Analisi Data}

Analisis data dilakukan secara univariat dan bivariat. Untuk univariat dilakukan dengan menggunakan statistik deskriptif, data akan disajikan dalam tabel distribusi frekuensi perilaku perawatan kaki dan kejadian kaki diabetes pada pasien. Secara analitik akan dianalisis dengan menggunakan uji chi square. Analisa data akan dilakukan dengan menggunakan program komputer yaitu SPSS (Statistical Package for the Social Sciences). 


\section{Hasil dan Pembahasan}

\subsection{Hasil Penelitian}

Tabel 1. Karakteristik Pasien Diabetes Berdasarkan Umur, Jenis Kelamin dan Tingkat Pendidikan

\begin{tabular}{lll}
\hline Kelompok Umur & Frekuensi & $\%$ \\
\hline Dewasa Akhir $(36-45$ tahun) & 3 & 3,6 \\
Lansia Awal (46-55 tahun) & 65 & 78,3 \\
Lansia Awal (46 - 55 tahun) & 15 & 18,1 \\
\hline Total & 83 & 100 \\
\hline & & \\
\hline Jenis Kelamin & Frekuensi (orang) & Persentase $(\%)$ \\
\hline Laki-laki & 28 & 33,7 \\
Perempuan & 55 & 66,3 \\
\hline Total & 83 & 100 \\
\hline & & \\
\hline Tingkat Pendidikan & Frekuensi & Persentase $(\%)$ \\
\hline Tidak Sekolah & 12 & 14,5 \\
SD & 16 & 19,3 \\
SMP & 30 & 36,1 \\
SMA & 21 & 25,3 \\
Perguruan Tinggi & 4 & 4,8 \\
\hline Total & 83 & 100 \\
\hline
\end{tabular}

Dari Tabel 1 dapat, dapat diketahui usia pasien diabetes mayoritas46-55 tahun (Lansia awal) tahun sebanyak 65 orang (78.3\%). Jenis kelamin terbanyak pada penderita diabetes adalah perempuan, yaitu sebanyak 55 orang $(66,3 \%)$, sedangkan tingkat pendidikan mayoritas SMP yaitu sebanyak 30 orang $(36,1 \%)$.

Tabel 2. Riwayat komplikasi luka kaki diabetes/ulkus

\begin{tabular}{lll}
\hline Riwayat Komplikasi Luka/Ulkus & Frekuensi & Persentase (\%) \\
\hline Ya & 29 & 34,9 \\
Tidak & 54 & 65,1 \\
\hline Total & 83 & 100 \\
\hline
\end{tabular}

Berdasarkan Tabel 2 dapat diketahui penderita diabetes sebagian besar tidak pernah mengalami komplikasi luka kaki diabetes/ulkus yaitu sebanyak 54 orang $(65,1 \%)$.

Tabel 3. Perilaku perawatan kaki pada penderita diabetes melitus

\begin{tabular}{lll}
\hline Tingkat Perilaku & Frekuensi & Persentase (\%) \\
\hline Baik & 35 & 42,2 \\
Kurang & 48 & 57,8 \\
\hline Total & 83 & 100 \\
\hline
\end{tabular}

Dari Tabel 3 diketahui perilaku perawatan kaki pada penderita diabetes lebih banyak mempunyai perilaku yang kurang yaitu sebanyak 48 orang $(57,8 \%)$ 
Tabel 4 Distribusi Frekuensi Perilaku Perawatan Kaki Berdasarkan Karakteristik Penderita Diabetes Melitus

\begin{tabular}{|c|c|c|}
\hline \multirow[t]{2}{*}{ Karakteristik } & \multicolumn{2}{|c|}{ Tingkat Perilaku } \\
\hline & Baik & Kurang \\
\hline \multirow[t]{2}{*}{ Laki-laki } & 1 & 1 \\
\hline & 2 & 6 \\
\hline \multirow[t]{2}{*}{ Perempuan } & 2 & 3 \\
\hline & 3 & 2 \\
\hline \multicolumn{3}{|l|}{ Umur } \\
\hline \multirow[t]{2}{*}{ Dewasa Akhir (36-45 tahun) } & 5 & 1 \\
\hline & & 5 \\
\hline \multirow[t]{2}{*}{ Dewasa Awal (46-55 tahun) } & 2 & 6 \\
\hline & 7 & 5 \\
\hline Dewasa Akhir (56-65 tahun) & 3 & 3 \\
\hline \multicolumn{3}{|l|}{ Tingkat Pendidikan } \\
\hline Tidak Sekolah & 4 & 8 \\
\hline \multirow[t]{2}{*}{ SD } & 6 & 1 \\
\hline & & 0 \\
\hline \multirow[t]{2}{*}{ SMP } & 1 & 1 \\
\hline & 7 & 3 \\
\hline \multirow[t]{2}{*}{ SMA } & 6 & 1 \\
\hline & & 5 \\
\hline Perguruan Tinggi & 2 & 2 \\
\hline \multicolumn{3}{|c|}{ Riwayat Komplikasi Luka Kaki Diabetes/Ulkus } \\
\hline \multirow[t]{2}{*}{$\mathrm{Ya}$} & 8 & 2 \\
\hline & & 1 \\
\hline \multirow[t]{2}{*}{ Tidak } & 2 & \\
\hline & 7 & \\
\hline
\end{tabular}

Berdasarkan Tabel 4 dapat diketahui berdasarkan jenis kelamin, lebih banyak wanita yang mempunyai perilaku baik yaitu 23 orang (27.7\%). Berdasarkan umur, mayoritas yang mempunyai perilaku baik adalah umur lansia awal (46-55 tahun) sebanyak 27 orang (38\%). Untuk tingkat pendidikan lebih banyak pendidikan SMP yang mempunyai pengetahuan baik 17 orang $(20.3 \%)$. Sedangkan untuk tingkat pendidikan perguruan tinggi semuanya mempunyai pengetahuan baik yaitu 2 orang $(100 \%)$.

\subsection{Hasil Analisis Data}

Tabel 5 Hubungan Perilaku Perawatan Kaki dengan terjadinya Komplikasi luka Kaki diabetes/ulkus

\begin{tabular}{|c|c|c|c|c|c|c|c|}
\hline \multirow{3}{*}{ Perilaku } & \multicolumn{4}{|c|}{ Komplikasi Luka Kaki Diabetes } & \multirow{2}{*}{\multicolumn{2}{|c|}{ Total }} & \multirow{3}{*}{ p-value } \\
\hline & \multicolumn{2}{|c|}{ Riwayat (+) } & \multicolumn{2}{|c|}{ Persentase $(\%)$} & & & \\
\hline & $\mathrm{n}$ & $\%$ & $\mathrm{~N}$ & $\%$ & $\mathrm{~N}$ & $\%$ & \\
\hline Baik & 8 & 27,6 & 27 & 50 & 35 & 42,2 & \\
\hline Buruk & 21 & 72,4 & 27 & 50 & 48 & 57,8 & $0,049 *$ \\
\hline Kurang & 29 & 100 & 54 & 100 & 83 & 100 & \\
\hline Total & 83 & & & 100 & & & \\
\hline
\end{tabular}


Hasil Tabel 5 dapat diketahui dari 35 orang yang mempunyai perilaku perawatan kaki yang baik terdapat 8 orang (27.6\%) yang mengalami komplikasi luka kaki diabetes, sedangkan dari 48 orang yang mempunyai perilaku yang buruk terdapat 21 orang $(72.4 \%)$ mengalami komplikasi. Hasil uji statistik chi squre menunjukkan terdapat hubungan yang signifikan antara perilaku perawatan kaki diabetes dengan terjadinya komplikasi luka kaki diabetes pada pasien diabetes di Puskesmas tuntungan Medan $(p<0.05)$.

\section{Hasil dan Pembahasan}

\subsection{Karakteristik Penderita Diabetes Melitus}

Pada penelitian ini penderita diabetes melitus ditemukan lebih banyak pada jenis kelamin perempuan dibandingkan laki-laki. Hal ini sejalan dengan penelitian Ariyanto (2014) yang menyatakan prevalensi DM tipe 2 lebih banyak terjadi pada perempuan yaitu sebanyak 77 orang $(81,92 \%)$, hal ini dikarenakan secara fisik perempuan memiliki peluang peningkatan indeks massa tubuh yang lebih besar seperti saat sindroma siklus bulanan (premenstrual syndrome), pasca-menopause dan wanita hamil. Menurut Gautam (2009), diabetes melitus juga merupakan penyakit yang diturunkan, sehingga penyakit ini cenderung lebih banyak terjadi pada perempuan akibat lebih tingginya angka kelahiran dengan jenis kelamin perempuan dibandingkan laki-laki.

Kelompok usia terbanyak penderita diabetes melitus yang ditemukan dari sampel berasal dari kelompok usia Lansia awal (46-55 tahun), yaitu sebanyak65orang (78.3\%). Hal ini sesuai dengan teori yang menyatakan usia sebagai salah satu faktor resiko diabetes mellitus. World Health Organization (WHO) dalam Putraet.al(2015) menyebutkan bahwa tiap kenaikan satu dekade umur pada seseorang yang telah melampaui usia 30, kadar glukosa darah puasa akan naik sekitar 1-2 mg/dL. Kurniawati (2011) juga menyatakan bahwa semakin tua seseorang maka risiko peningkatan kadar gula darah dan gangguan toleransi glukosa akan semakin tinggi, hal ini disebabkan melemahnya semua fungsi organ tubuh termasuk sel pankreas yang bertugas menghasilkan insulin. Menurut Haltomi (2012), diabetes melitus dapat terjadi pada semua kelompok usia terutama di atas 40 tahun karena resiko terkena DM akan meningkat dengan bertambahnya usia dan biasanya terjadi pada usia diatas 40 tahun.

Sebagian besar tingkat pendidikan penderita diabetes mellitus merupakan tamatan SMP yaitu sebanyak 30 orang (36,1\%).Hal ini sejalan dengan penelitian Juwitaningtyas (2014), pendidikan pasien diabetes melitus terbanyak pada tamatan SMP yaitu sebanyak 10 orang $(31,1 \%)$.Baur, et al. (2013) juga menyatakan bahwa tingkat pendidikan mayoritas pasien diabetes melitus di India merupakan tamatan SMP yaiu sebanyak 162 orang $(45,8 \%)$.

Dari 56 pasien diabetes, 54 orang $(65,1 \%)$ tidak pernah mengalami komplikasi ulkus dan 29 orang $(34,9 \%)$ pernah mengalami komplikasi ulkus. Menurut Iraj (2013), sekitar 15-25\% penderita diabetes mellitus akan mengalami komplikasi ulkus dan sekitar 70\% dari penderita ulkus akan mengalami eksaserbasi penyakit dalam 5 tahun ke depan. Ulkus yang sudah terjadi akan sering mengalami infeksi dan menyebabkan angka rujukan ke rumah sakit meningkat. Selain itu, ulkus pada kaki menyumbangkan lebih dari setengah kasus amputasi kaki yang bukan diakibatkan trauma.

\subsection{Perilaku Perawatan Kaki Penderita Diabetes Melitus}

Perilaku perawatan kaki pada penderita diabetes melitus dijumpai lebih banyak tingkat perilaku kurang, hal ini dapat disebabkan karena pengetahuan mengenai perawatan kaki juga buruk. Menurut Notoatmodjo (2003), pengetahuan merupakan domain yang sangat penting untuk terbentuknya tindakan atau perilaku seseorang. Hal ini sejalan dengan Desalu, et al. (2011) yang menyatakan perilaku perawatan kaki yang buruk disebabkan karena kurangnya pengetahuan tentang perawatan kaki. Menurut Qadi dan Al Zahrani (2011) menyatakan bahwa terdapat korelasi antara pengetahuan perawatan kaki dengan perilaku perawatan kaki, hal ini menegaskan pentingnya pendidikan perawatan kaki serta meningkatkan pengetahuan merupakan langkah pertama dalam meningkatkan praktek perawatan kaki pada penderita diabetes melitus.

Berdasarkan jenis kelamin, hasil penelitian menunjukkan bahwa lebih banyak perempuan yang mempunyai pengetahuan baik, hal ini sejalan dengan, hasil ini sesuai dengan penelitian yang dilakukan oleh Berhe, Kahsay dan 
Gebru (2013) di mana laki-laki lebih buruk dalam menjalankan praktik perawatan kaki. Penelitian Iversen (2009) juga menunjukkan bahwa laki-laki merupakan variabel independen yang berkorelasi negatif dengan tingkat perilaku perawatan kaki pada penderita diabetes melitus tipe 2. Namun, pada penelitian Wendling dan Beadle (2015) didapati perilaku wanita lebih buruk dibandingkan pria dengan skor rata-rata wanita 74.11 dan pria 77.2. Pada penelitian Diani (2013) menunjukkan perempuan memiliki perilaku perawatan kaki yang buruk. Sulit untuk menjelaskan bagaimana jenis kelamin mempengaruhi perilaku perawatan kaki, namun diperkirakan hal ini berhubungan dengan variabel lain, salah satunya pengetahuan.

Tingkat perilaku berdasarkan tingkat pendidikan dijumpai pada tingkat pendidikan tidak sekolah, SD, dan SMA lebih banyak yang memiliki perilaku kurang. Sedangkan, pada tingkat pengetahuan SMP dijumpai lebih banyak yang memiliki perilaku baik. Hasil ini sejalan dengan hasil penelitian Khatak, et al. (2014) di mana tingkat pendidikan mempengaruhi praktik perawatan kaki dengan pendidikan yang lebih tinggi menunjukkan perilaku yang lebih baik. Penelitian Berhe, Kahsay dan Gebru (2013) juga menunjukkan hasil yang sama. Penelitian Diani (2013) juga menunjukkan klien diabetes melitus tipe 2 yang berpendidikan tinggi memiliki perilaku yang baik pula.

Tingkat perilaku berdasarkan riwayat komplikasi ulkus dijumpai pada penderita yang pernah mengalami komplikasi ulkus lebih banyak berperilaku buruk. Hal ini sesuai dengan penelitian Hellenberg dan Thunberg (2013) yang mengatakan perilaku baik mengurangi risiko terjadinya ulkus kaki.

\subsection{Hubungan Perilaku Perawatan Kaki dengan Terjadinya Komplikasi Luka Kaki Diabetes}

Dari penelitian didapatkan bahwa faktor perilaku perawatan kaki dapat dipengaruhi oleh banyak faktor termasuk pengetahuan, tingkat pendidikan, jenis kelamin serta riwayat komplikasi kaki sebelumnya. Dari berbagai faktor tersebut faktor yang berperan penting adalah pengetahuan pasien diabetes yang masih kurang tentang perawatan kaki. Hal ini diketahui ketika melakukan wawancara dengan pasien, mereka menyatakan selama ini tidak pernah diberikan edukasi khusus tentang perawatan kaki, perawatan kaki tidak dianggap bagian penting dalam manajemen pasien diabetes, sehingga penderita diabetes tidak melakukan perawatan yang tepat untuk kaki, sehingga kaki lebih beresiko untuk terjadi komplikasi. Hal ini sejalan dengan penelitian Diani (2013) dan George, et al. (2016) yang menunjukkan bahwa pengetahuan tentang perawatan kaki yang buruk akan menghasilkan perilaku perawatan kaki yang buruk pula. Hasil ini juga sejalan dengan penelitian Desalu, et al. (2011) bahwa pengetahuan yang baik memiliki perilaku perawatan kaki yang baik pula. Wendling dan Beadle (2015) juga menunjukkan adanya efikasi diri dengan perilaku perawatan kaki pada penderita diabetes. Khatak, et al. (2014) juga menunjukkan korelasi positif antara tingkat pengetahuan dengan perilaku perawatan kaki. Gholap dan Mohite (2013) dalam penelitiannya di India juga menyatakan bahwa terdapat korelasi yang sempurna antara pengetahuan dan perilaku perawatan kaki pada pasien diabetes.Hasil ini mengimplikasikan pentingnya pengetahuan sebagai variabel yang menentukan perilaku perawatan kaki dan perlunya edukasi untuk meningkatkan pengetahuan perawatan kaki yang akhirnya meningkatkan perilaku perawatan kaki. Perilaku perawatan kaki yang lebih baik akan mengurangi risiko terjadinya komplikasi ulkus kaki dan berujung pada kualitas hidup pasien. Pencegahan ulkus kaki lebih penting dilakukan karena pengobatan ulkus kaki memakan waktu dan sumber daya yang lebih besar.

\section{Kesimpulan}

Pada penelitian ini dapat diketahui bahwa terdapat hubungan perilakuperawatan kaki dengan terjadinya komplikasi luka kaki diabetes pada pasienDM tipe 2di Puskesmas Tuntungan Medan. Perilaku perawatan sangat dipengaruhi oleh pengetahuan pasien diabetes, untuk itu edukasi tentang perawatan kaki sangat penting diberikan sebagai upaya pencegahan komplikasi luka kaki diabetes.

\section{Daftar Pustaka}

[1] Al-Asmary, A.S., Mostafa, O.S.A. dan Al-Khaldi, Y.M.,2013. Diabetic Patients' Knowledge and Practice Regarding Prevention of Diabetic Foot. Med. J. Cairo Univ, 81(2), pp.197-205.

[2] American Diabetes Association: Diabetes statistics. Available at: www.diabetes.org/diabetes-statistics.jsp[Accessed 28 May 2016]. 
[3] Ariyanto, R.W., 2014. Karakteristik Faktor - Faktor Risiko Kejadian Diabetes Mellitus Tipe 2 pada Pasien di RSUD Labuang Baji Makassar Periode Juli - Desember 2013. Skripsi. Fakultas Kedokteran Universitas Hasanuddin. Makasar.

[4] Ayuningtyas, M.F., 2010. Evaluasi Drug Therapy Problems Obat Hipoglikemia Kombinasi Pada Penderita Geriatri Diabetes Melitus Tipe 2 di Instalasi Rawat Jalan RSUP Dr. Sardjito Yogyakarta Periode Januari-Juni 2009, Yogyakarta, Fakultas Farmasi Universitas Sanata Dharma.

[5] Baur, B., Manna, N., Sarkar, J., Basu, G., Bandyopadhyay, L. dan Bhattacharya, K., 2013.An epidemiological study on risk factors of diabetes mellitus among the patients attending a tertiary care hospital of West Bengal, India.GJMEDPH, 2(4), pp.1-7.

[6] Berhe, K.K., Kahsay, A.B. dan Gebru, H.B., 2013. Adherence to Diabetes Self-Management Practices among Type II Diabetic Patients in Ethiopia; A Cross Sectional Study. Greener Journal of Med Sci, 3(6), pp.211-221

[7] Bruner dan Sudarth, 2002.Ilmu Keperawatan Medical Bedah.Jakarta. EGC.

[8] Chiwanga, F.S. dan Njelekela, M.A., 2015. Diabetic foot: prevalence, knowledge, and foot self-care practices among diabetic patients in Dar es Salaam, Tanzania - a cross-sectional study. Journal of Foot and Ankle Research, 8(20), pp.1-7.

[9] Desalu, O.O., Salawu, F.K., Jimoh, A.K., Adekoya, A.O., Busari, O.A. dan Olokoba, A.B., 2011. Diabetic Foot Care: Self Reported Knowledge And Practice Among Patients Attending Three Tertiary Hospital In Nigeria. Ghana Medical Journal, 45(2), pp.60-65.

[10] Diani, N., 2013.Pengetahuan dan Praktik Perawatan Kaki Pada Klien Diabetes Melitus Tipe 2 di Kalimantan Selatan. Tesis. Program Magister Keperawatan Kekhususan Keperawatan Medikal Bedah Fakultas Ilmu Keperawatan Universitas Indonesia. Depok.

[11] Ekore, R.I., Ajayai, I.O., Arije, A. dan Ekore, J.O., 2010. Knowledge of and attitude to foot care amongst Type 2 diabetes patients attending a university-based primary care clinic in Nigeria. African Journal of Primary Health Care \& Family Medicine, 2(1), pp.1-3.

[12] Fatimah, R.N.. 2015. Diabetes Melitus Tipe 2. Jurnal Majority, 4(5), hlm.9101.

[13] Frykberg, R.G., et al., 2006. Diabetic Foot Disorders: A Clinical Practice Guideline. American College of Foot and Ankle Surgeons, 45(5), pp.6-24.

[14] Gautam, Y., Sharma, Bhatnagar, M.K. dan Trehan, R.R., 2009. A cross sectional study of QOL of diabetic patient at tertiary care hospital in delhi.Indian journal of community medicine.

[15] George, H., Rakesh, P.S., Krishna, M., Alex, R., Abraham, V.J., George, K. dan Prasad, J.H., 2013. Foot Care Knowledge and Practices and the Prevalence of Peripheral Neuropathy Among People with Diabetes Attending a Secondary Care Rural Hospital in Southern India. JFMPC, 2(1), pp.27-32.

[16] Gholap, M.C. dan Mohite, V.R., 2013.To Assess the Knowledge and Practice Regarding Foot Care among Diabetes Patients at Krishna Hospital, Karad.Indian J.Sci.Res, 4(2), pp.69-75.

[17] Hasnanin, S. dan Sheikh, N.H., 2009. Knowledge and practices regarding foot care in diabetic patients visiting diabetic clinic in Jinnah Hospital, Lahore. J Pak Med Assoc, 59(10), pp.687-690.

[18] Hastuti, R.T., 2008. Faktor-Faktor Risiko Ulkus Diabetika pada Penderita Diabetes Melitus. Semarang: Universitas Diponegoro.

[19] Hellenberg, S. dan Thunberg, S., 2013. Knowledge and Practices Regarding Foot Care Among Patients with Type 2 Diabetes in Ho Chi Minh City, Vietnam. Uppsala Universitet.pp.1-42.

[20] Heltomi, M., 2012. Profil Klinis Dan Laboratorium Penderita Diabetes Melitus Tipe II Di Instalasi Penyakit Dalam RSUD Dr. H. Abdoel Moeloek Provinsi Lampung Periode Juni-Desember 2010.

[21] International Diabetes Federation, 2013. IDF Diabetes Atlas. Six edition from www.idf.org/diabetesatlas.[Accessed 28 May 2016].

[22] Iraj, B., Khorvash, F. dan Askari, G., 2013. Prevention of Diabetic Foot Ulcer.International Journal of Preventive Medicine, 4(3), pp.373376.

[23] Iversen M.M., 2009. An Epidemiologic Study of Diabetes-related Foot Ulcers. Bergen University.pp.1-8.

[24] Juwitaningtyas, F.M., 2014. Pengaruh Pendidikan Kesehatan terhadap Peningkatan Pengetahuan dan Sikap Penderita Diabetes Mellitus dalam Pencegahan Luka Kaki Diabetik di Desa Mranggen Polokarto Sukoharjo. Skripsi. Program Sarjana Keperawatan Fakultas Ilmu Kesehatan Universitas Muhammadiyah Surakarta. Surakarta.

[25] Kemenkes RI, 2013. Health Statistics. Jakarta: Pusat Data dan Informasi Profil Kesehatan Indonesia 2012. http://www.kemkes.go.id[Accesed 28 May 2016]

[26] Khatak, M.B., Marwat, Z.I., Usman M. dan Sljjad A., 2014. Evaluation of Foot Care Knowledge and Practices Among Diabetic Patients Attending Tertiary Care Hospital. KJMS, 7(2), pp.184-189.

[27] Khotimah, K., 2013. Gambaran Faktor Risiko Diabetes Melitus Tipe 2 Di Klinik Dr. Martha ungaran. Program Studi Kesehatan Masyarakat, Stikes Ngudi Waluyo, Ungaran.

[28] Kumar, A., Ranjan, A., Chand, G., Kumar, D., Singh, S.K. dan Kumar, V., 2015. The Foot Care Process of Diabetic Patients (With and Without Foot Ulcer) Attending A Tertiary Care Hospital in India. J Stem Cell Res Ther, 5(5), pp.1-6.

[29] Kurniawati, D.M., 2011. Perbedaan Perubahan Berat Badan, Aktivitas Fisik dan Kontrol Glukosa Darah Antara Anggota Organisasi Penyandang Diabetes Melitus dan Non Anggota. Skripsi. Program Studi Ilmu Gizi Fakultas Kedokteran Universitas Diponegoro. Semarang.

[30] Madanchi, et al.,2013. Who are diabetic foot patients? A descriptive study on 873 patients. Journal of Diabetes and Metabolic Disorder, 12, pp.36

[31] Morison, M. J., 2013. Manajemen Luka. Jakarta: EGC.

[32] Muhammad-Lutfi, A.R., Zaralhah, M.R. dan Anuar-Ramdhan, I.M.,2014. Knowledge and Practice of Diabetic Foot Care in an In-Patient Setting at a Tertiary Medical Center. Malaysian Othopaedic Journal, 8(3), pp.22-26.

[33] Notoatmodjo, S., 2003. Pendidikan dan Perilaku Kesehatan. Jakarta: Rineka Cipta.

[34] PERKENI, 2006. Konsensus Pengelolaan dan Pencegahan Diabetes Melitus Tipe 2 di Indonesia. Jakarta: Kongres Persadia 
[35] Pollock, R.D., Unwin, N.C. dan Connolly, V., 2004. Knowledge and practice of foot care in people with diabetes. Diabetes Research and Clinical Practice, 64, pp.117-122.

[36] Pramesti, D.E., 2010. Perbedaan Pengetahuan Tentang Perawatan Kaki pada Penderita Diabetes Mellitus Sebelum dan Sesudah Dilakukan Pendidikan Kesehatan Di Desa Kedunggading Kecamatan Ringinarum Kabupaten Kendal. Skripsi. Program Studi Ilmu Keperawatan STIKES Ngudi Waluyo Ungaran. Semarang

[37] Priantono, D. dan Sulistianingsih, D.P., 2014.Kapita Selekta Kedokteran Ed. IV. Jakarta: Media Aesculapius, hlm.792-796.

[38] Price, S. dan Wilson, L., 2012.Patofisiologi: Konsep Klinik, Proses-proses penyakit, Edisi 6 vol 2. Jakarta: Buku Kedokteran.

[39] Putra, A.L., Wowor, P.M. dan Wungouw, H.I.S., 2015. Gambaran Kadar Gula Darah Sewaktu Pada Mahasiswa Angkatan 2015 Fakultas Kedokteran Universitas Sam Ratulangi Manado. Journal e-Biomedik, 3(3), pp.834-838.

[40] Qadi, M.A. dan Al Zahrani, H.A., 2011. Foot Care Knowledge and Practice among Diabetic Patients Attending Primary Health Care Centers in Jeddah City. JKAU: Med. Sci, 18(2), pp.55-71.

[41] Rocha, R.M., Zanetti, M.L. dan Santos, M.A.D., 2009. Behavior and knowlege: basis for prevention of diabetic foot. Acta Paul Enferm, 22(1), pp.17-23.

[42] Sundari, A., Aulawi, K. dan Harjanto, D., 2009. Gambaran Tingkat Pengetahuan Tentang Ulkus Diabetik dan Perawatan Kaki pada Pasien Diabetes Melitus Tipe 2. JIK, 4(3), pp.181-190.

[43] Suyono, S., 2006. Diabetes melitus di Indonesia. Dalam : Aru W, dkk, editor, Ilmu Penyakit Dalam, Jilid III, Edisi 4, Jakarta: FK UI

[44] Wendling, S., Beadle V., 2015. The Relationship Between Self-efficacy and Diabetic Foot Self-care. Jour of Clin \& Translational Endocrinology, (2), pp.37-41.

[45] World Health Organization, 2015. Diabetes Melitus. http://www.who.int/en/ 